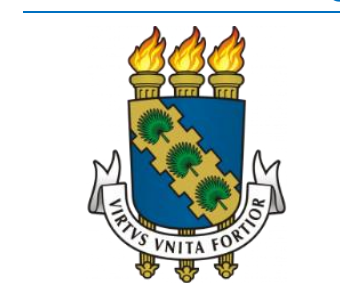

\title{
CONTEXTUS
}

REVISTA CONTEMPORÂNEA DE ECONOMIA E GESTÃO

Contextus - Contemporary Journal of Economics and Management

FEDERAL UNIVERSITY

ISSN 1678-2089

of Ceará

www.periodicos.ufc.br/contextus

ISSNe 2178-9258

\section{Luxury brands: Awareness and image and its influence on loyalty and engagement}

\section{Marcas de luxo: Conscientização e imagem e sua influência na lealdade e no engajamento}

\section{Marcas de lujo: Notoriedad e imagen y su influencia en la lealtad y el engagement}

\section{Valentín Gallart-Camahort}

https://orcid.org/0000-0001-6194-2614 (D)

Researcher at the Cardenal Herrera University

$\mathrm{PhD}$ in Business Administration and

Marketing from Jaume I University

valentin.gallart@uchceu.es

\section{Eugenio De la Oliva Ramos}

https://orcid.org/0000-0002-1837-1331 (i)

Graduate in Business Management and Marketing from Cardenal Herrera University

eugenio.de@alumnos.uchceu.es

\section{Laura Fernandez-Duran}

https://orcid.org/0000-0003-1780-7188 (D) $\mathrm{PhD}$ in Business Administration from Cardenal Herrera University

laura.fernandez5@uchceu.es

https://doi.org/10.19094/contextus.2021.71415 di)

\section{ABSTRACT}

Since engagement is a relatively new concept in the field of marketing and is not usually included when studying brand equity, this paper aims to analyze what role engagement has in its relationship with the creation of value for luxury brands. A theoretical model was specified and tested by confirmatory factor analysis. Hypothesis have been tested running a structural equations model. Each hypothesis has resulted to be significant. The conclusions obtained from the analysis of the data allow us to describe the effects that occur between the variables, being important for their management so that managers of the luxury companies can increase the value of their brands.

Keywords: luxury brands; brand awareness; brand image; brand loyalty; engagement.

\section{RESUMO}

Como o engajamento é um conceito relativamente novo no campo do marketing e não costuma ser incluído no estudo do brand equity, este artigo tem como objetivo analisar o papel que o engagement tem em sua relação com a criação de valor para marcas de luxo. Um modelo teórico foi especificado e testado por análise fatorial confirmatória. As hipóteses foram testadas executando um modelo de equações estruturais. Cada hipótese resultou ser significativa. As conclusões obtidas a partir da análise dos dados permitem descrever os efeitos que ocorrem entre as variáveis, sendo importantes para a sua gestão para que os gestores das empresas de luxo possam aumentar o valor das suas marcas.

Palavras-chave: marcas de luxo; conscientização da marca; imagem de marca; fidelidade à marca; engajamento.

\section{RESUMEN}

Puesto que engagement es un concepto relativamente nuevo en el ámbito del marketing y no se suele incluir cuando se estudia brand equity, el presente trabajo pretende analizar qué papel tiene engagement en su relación con la creación de valor para las marcas de lujo. Un modelo teórico fue especificado y probado por análisis factorial confirmatorio. Las hipótesis se han probado mediante un modelo de ecuaciones estructurales. Cada hipótesis ha resultado ser significativa. Las conclusiones obtenidas del análisis de los datos nos permiten describir los efectos que se producen entre las variables, siendo importantes para su gestión para que los directivos de las empresas de lujo puedan incrementar el valor de sus marcas. Palabras clave: marcas de lujo; notoriedad de marca; imagen de marca; lealtad a la marca; compromiso.

\section{Article Information}

Uploaded on 13 July 2021

Final version on 29 August 2021

Accepted on 29 August 2021

Published online on 4 October 2021

Interinstitutional Scientific Committee Editor-in-chief: Diego de Queiroz Machado Evaluation by the double blind review system (SEER / OJS - version 3)

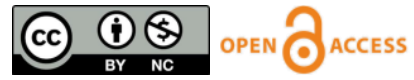

How to cite this article:

Gallart-Camahort, V., Ramos, E. O., \& Fernandez-Duran, L.(2021). Luxury brands: Awareness and image and its influence on loyalty and engagement. Contextus Contemporary Journal of Economics and Management, 19(20), 305-315. https://doi.org/10.19094/contextus.2021.71415 


\section{INTRODUCTION}

As per data from the Best Global Brands 2018 report by Interbrand, luxury brands are leading the growth of the world's best brands in percentage terms. As Kim and Ko (2012) indicate, this strengthens that the basis of this high added value industry is brand assets.

In the literature of recent years there has been a growth of studies on the marketing of luxury products and services (Ko et al., 2017) taking into account the importance of the brand in this industry and its multiple connotations, both the name, logo, symbol and identity, like all tangible and intangible attributes (Prasad \& Dev, 2000).

As per Xi and Hamari (2020), two key components of brand equity are awareness and loyalty. Although brand awareness, image and loyalty are dimensions that have served, to a great extent, as a common denominator in brand equity studies, engagement seen from the perspective of one of the dimensions that affects brand equity is relatively new, as brand engagement is relatively a new concept in marketing (Farha et al., 2020).

Taking into account the Theory of Planned Behavior proposed by Ajzen (1991) that suggests that behavior is determined by intentions, attitudes, and subjective norms, the present study proposes the inclusion of engagement in the study of value creation for brands of the luxury sector. Engagement is an individual difference that represents the propensity of consumers to include important brands as part of how they see themselves (Sprott et al., 2009) and that is why there is a need to relate engagement to value brand in the luxury sector.

This interest in the luxury market is new since, despite the importance of luxury brands in the lives of consumers and the fact that they represent an important part of the economic activities of the industrialized world, little is known about the influence of dimensions in the brand equity of luxury brands (Vigneron \& Johnson, 2004). Due to this, this work seeks to provide more information about this specific topic both in the theoretical and empirical fields. This paper analyzes how brand awareness affects loyalty and engagement in luxury brands through the brand image as a mediator.

\section{THEORETICAL FRAMEWORK}

\subsection{Luxury Brands}

Kapferer (1997) defines luxury as beauty and good taste in itself, although the definitions found in the literature are diverse. Thus, Dubois et al. (2001) identify six facets that define and structure it: excellent quality, high price, exclusivity, aesthetics, personal history and superfluity. In this same line Keller (2009) takes into account ten characteristics that define luxury: the maintenance of a premium image, the creation of intangible brand associations, alignment with quality, logos, symbols and packaging as drivers of the value of brand, secondary associations linked to personalities, events, countries and other entities, controlled distribution, premium pricing strategy, carefully managed brand architecture, broadly defined competition and legal protection of the brand. From a price point of view, luxury brands are those whose functionality-price ratio is low and situational utility-price is high (Nueno \& Quelch, 1998).

However, Berthon et al. (2009) states that luxury is more than a series of characteristics and attributes, conceptualizing it in three different spheres: (1) the objective (material), referring to the use of high quality raw material, high functionality and performance, (2) the subjective (individual), which consists of the personal hedonic value that the consumer gives to the brand and (3) the collective (social), the brand being understood as a signal to others.

Likewise, we can see how several authors give greater importance to the experience, perception and connection of the consumer with the brand. Luxury brands offer premium products, providing pleasure as a core benefit and connecting with consumers emotionally (Hagtvedt \& Patrick, 2009).

Consumers don't buy fashion brands for logical reasons; they buy for emotional reasons (Ismail, 2015). Heine (2012) states that luxury brands are associated with consumer perceptions such as high price, quality, aesthetics, and a high level of non-functional associations. In this case, the only material characteristics of the product were left aside to focus on the impression that people have of different brands.

For Kotler and Keller (2016), luxury products are the purest examples of the role that branding plays, since the brand and its image are usually key competitive advantages that create enormous wealth and value. This reveals the importance of the brand in a highly competitive industry that needs to constantly generate value through its tangible and intangible assets.

A strong brand equity is a sign that there are favourable associations towards the brand by consumers and stakeholders, differentiating one brand from another (Shamma \& Hassan, 2011). Likewise, brand equity was considered to give the opportunity to make successful brand extensions, resist the different promotional pressures of competitors and the creation of entry barriers (Farquhar, 1989). Brand equity is understood as the difference in consumer choice between a branded product and one without a brand, both having the same characteristics (Yoo et al., 2000).

Aaker (1996) considers that the dimensions of brand equity are brand loyalty, perceived quality, brand associations and awareness. This multidimensional concept is based mainly on the perceptions that consumers have about a brand. The author considers that these dimensions represent an effective measure for the value of the brand, being sensitive to detect changes and may be applicable between brands, product categories and markets.

On the other hand, Keller (1993) works on the dimensions of brand equity under brand awareness, so it is necessary for the consumer to have a positive relationship with the brand. This concept proposed by the author is composed of two elements: brand awareness (which means 
brand recognition) and brand image (defined as perceptions and reflections of the brand in the consumer's mind).

\subsection{Luxury Brand Awareness and Luxury Brand Image}

For Aaker (1996), awareness reflects the outstanding feature of the brand in the mind of the consumer. Likewise, the author considers that there are six types of awareness: (1) recognition, (2) recall, (3) top of mind, (4) brand dominance, (5) brand awareness and (6) brand opinion. It is also emphasized that awareness goes beyond a mere name, with the same importance as the symbols or images.

Along the same lines, Keller (2003) defines brand awareness as "the ability of consumers to remember and recognize the brand as reflected by their ability to identify the brand under different conditions and relate it to a name, logo and symbol, as well as certain associations in his memory". So, it is understandable that high levels of brand awareness can increase the choice of a brand by the consumer (Keller, 1993).

According to the work of Romaniuk et al. (2017) brand awareness is a capacity of a given customer to recognize or recall that a given brand belongs to a particular category of products. Brand awareness means being aware of its existence and its relationship with a particular product (Switala et al., 2018). Customers have a tendency to pay more money for known and famous brands (Keller, 1993). Practically, brand awareness indicates the effectiveness of marketing activities of each company (Liu et al., 2010). Seetharaman, Nadzir, and Gunalan (2001) indicate that the demand for a certain brand increases when more awareness and acceptance of the brand is created among customers.

There are several studies that highlight the interaction between brand awareness, image and brand loyalty (Martínez et al., 2014; Sasmita \& Suki, 2015; Aberdeen et al., 2016). Brand image is created by a set of features of an extraordinary nature, unique for a given brand, which cause its differentiation, simultaneously ensuring the desired market recognition (Switala et al., 2018).

Chang (2012) and Barreda (2015) stated that high brand awareness contributes to other brand factors such as brand image. Bilgin (2018) in his study on social media marketing activities points out that "brand awareness has a significant effect on brand image".

As a consequence of these studies, the first hypothesis to consider in this paper is:

H1: Brand awareness positively affects brand image in the luxury sector.

\subsection{Luxury Brand Awareness and Loyalty}

Getting customers loyal to the brand has been shown to be vital to achieve the profitability and survival of companies. Loyal customers generally have a higher payment intention and lower price sensitivity compared to other customers (Jorgensen et al., 2016).

The ability to create customer loyalty is an important goal of brand management. For Keller (2003), achieving brand loyalty is the main source of generating value for a brand from the customer's perspective.

For authors such as Gremler and Brown (1996), loyalty consists in the degree to which the customer manifests a repeat purchase behaviour of a specific supplier and also has a predisposition towards that supplier, taking only this supplier into account when the need to consume their services arises.

Aaker (1991, 1996) defines brand loyalty as a customer's attachment to a brand. In general, we can say that brand loyalty has been considered an attitude or behaviour (Odin et al., 2001). Thus, authors such as Rauyruen and Miller (2007) define consumer loyalty as a concept formed by an attitudinal and a behavioural dimension. For Castaldo et al. (2015), loyalty is the degree to which a regular customer shows purchase intention with his supplier, has a disposition of positive attitude towards him and goes to him every time the need arises.

Brand awareness can positively affect the loyalty a consumer has with a brand. MacDonald and Sharp (2000) indicate that, although consumers may show curiosity for different brands, they will also prefer one already known either for wanting to maintain their heuristic habits or for the guarantee of quality and popularity (Tybout \& Artz, 1994).

The relationship between brand awareness and loyalty has been studied numerous times by different researchers. Boo et al. (2008) developed two different models in which, among other things, they tried to analyze the degree to which loyalty can be affected by awareness. A high level of brand awareness has several advantages in the customer purchase decision-making process such as learning advantage, consideration advantage, and choice advantage (Sürücü et al., 2019). As per Wu et al. (2020), brand awareness is an important antecedent of brand loyalty. In his study applied to retail, Das (2014) points out that the retailer awareness positively influences retailer loyalty. In the sector of tourist destinations Kotsi et al. (2018) conclude that destination brand awareness is positively related to destination brand loyalty. Bilgin (2018) concludes that "brand awareness has a significant effect on brand loyalty".

Taking into account the existing literature, the hypothesis that relates brand awareness to loyalty in the field of luxury is presented:

H2: Brand awareness positively affects brand loyalty in the luxury sector

\subsection{Luxury Brand Awareness and Engagement}

Customer engagement is an increasingly relevant and researched topic (Banyte \& Dovaline, 2014). In other academic disciplines such as sociology or political science they have used the term "engagement" in a large number of academic articles, but, on the other hand, little literature related to marketing prior to 2005 refers to customer engagement (Brodie et al., 2011).

Luxury brands have embraced the social media era through marketing communication pointing out the particular attributes of luxury such as high quality, rich pedigree, rarity, 
personality, placement, public relations and figures as well as a typically high pricing, to drive consumer engagement. Brand engagement, customer engagement, consumer engagement, or simply engagement, are among the various names given to the same concept (Dhaoui, 2014).

Engagement can be understood as a state in which one is involved, busy and totally absorbed in something generating consequences in forces of attraction or repulsion (Higgins and Scholer, 2009).

Bowden (2009) defines engagement as a psychological process that models mechanisms that make it possible to obtain and maintain consumers. It is also considered a mental state that presents emotional, cognitive and behavioural levels in the different interactions with the brand (Hollebeek, 2011). Grassi (2020) considers that engagement is associated with the ideas of sincerity, access, implication, relationship, acceptance, inclusion and relationship between equals.

For Patterson et al. (2006) engagement is defined as the level of the physical, cognitive and emotional presence of a consumer in the relationship with an organization. On the other hand, Vivek et al. (2010) places special emphasis on the fact that this connection between a consumer and a company can be initiated by either of them.

Engagement allows both participants of the purchase process to benefit. The company gains competitive advantage and the consumer obtains greater satisfaction (Rajah et al., 2008; Auh et al., 2007). Consumers who have engagement become partners of the brand, with which they cooperate in the process of creating value by satisfying the needs of other consumers, and thus consumers become cocreators (Sashi, 2012). In other words, consumers who have an active engagement to the brand provide useful information for the company and help create brands that respond to the individual needs of consumers (Kuvykaite \& Piligrimiene, 2014).

A brand that has consumers with engagement will have positive consequences, both financial and nonfinancial, in the short and medium term (Van Doorn, 2010). Engagement represents a strategic imperative with advantages such as improving corporate performance, increasing sales (Neff, 2007), competitive advantage and greater profitability (Voyles, 2007).

In this way, the importance of an engaged consumer to a brand is reflected. These provide references and recommendations to others about the different products or services offered by the brand and, likewise, these consumers can play a key role in the development of new products or services (Hoyer et al., 2010).

Bowden (2009) defined engagement as a "psychological process that models the underlying mechanisms by which customer loyalty forms for new customers of a service as well as mechanisms by which loyalty may be maintained for repeat purchase customers of a service brand". Pansari and Kumar (2017) defined customer engagement as the mechanics of customer value added to the firm through direct and/or indirect contributions.
Research has indicated that engaged consumers showed greater loyalty to brands (Hollebeek, 2011). Brand awareness affects the decision-making process of consumers, and identified brands are more likely to be included in consumers' consideration sets and increase choices (Huang \& Sarigöllü, 2012).

Knowing the different dimensions proposed by the aforementioned authors, being common denominators of most of the research studies of brand value, this paper aims to analyze the relationship between brand awareness, brand image, brand loyalty and engagement in the luxury sector, since, as indicated by Gómez et al. (2019), the consumer brand engagement construct is still in its infancy.

That is why this paper aims to analyze how brand awareness affects engagement in the luxury brand sector:

H3: Brand awareness positively affects engagement in the luxury sector.

\subsection{Luxury Brand Image and Loyalty}

For Aaker (1996), awareness reflects the outstanding feature of the brand in the mind of the consumer. Likewise, the author considers that there are six types of awareness: (1) recognition, (2) recall, (3) top of mind, (4) brand dominance, (5) brand awareness and (6) brand opinion. It is also emphasized that awareness goes beyond a mere name, with the same importance as the symbols

Kotler (2002) defines image as the set of beliefs, ideas, and impressions that a person develops for an object and states that attitudes and actions toward an object, such as a product or service, are highly conditioned by that object's image.

Brand image can be defined as the perceptions of a brand as a result of the brand associations that the consumer keeps in his memory. These brand associations are informational nodes related to the brand node in the consumer's memory, containing the meaning of the brand for it (Keller, 1993). Aaker (1991), meanwhile, defines the brand image as a set of related brand associations in a significant way, understanding these as everything related to the brand in memory.

The importance that brand image has acquired in different investigations consists mainly of three points: (1) It has the capacity to increase the added value (Wood, 2000), (2) it is an important source of brand value (Keller, 2003; Lassar et al., 1995) and (3) consumers constantly base their purchase decisions on the perceptions obtained from a company's brand image (Kim \& Kim, 2005).

Brand image has a strong relationship with both present and future loyalty (Hanzaee \& Farsani, 2011) being this link between both dimensions increasingly accepted by researchers (Jara \& Cliquet, 2012; Johnson et al., 2001; Andreassen \& Lindestand, 1998). As indicated by Greve (2014) in his study about a Facebook fan page of the students of the Hamburg School of Business Administration, the influence of brand image on brand loyalty is supported.

As per Kotsi et al. (2018) tourism destination brand image is positively related to tourism destination brand 
loyalty. Bilgin (2018) concludes that "brand image has a significant effect on brand loyalty".

Based on the definitions explained above and the suggested relationship between brand image dimensions and brand loyalty, the following hypothesis is formulated:

H4: Brand image positively affects brand loyalty in the luxury sector.

\subsection{Luxury Brand Image and Engagement}

According to Rappaport (2007), the high relevance of brands to consumers and the development of an emotional connection between consumers and brands is what the brand commitment focuses primarily on. The reaction of the consumer with the activities related to the brand and its response to the communications of other consumers result in the creation of more brand value (Schivinski \& Dabrowski, 2015). As per Matos and Rossi (2008), brands with a high reputation or high levels of brand value are more likely to have high levels of positive customer engagement.

Taking into account the role that engagement currently plays in recent studies in which it is seen as a new metric to measure brand performance (Hollebeek et al., 2014) customer engagement is taking on a prime role in the marketing literature and is considered a driving force in contemporary consumer behaviour research (Gambetti \& Graffigna, 2010).

For Greve (2014) the hypothesis that the stronger the brand image, the higher the engagement activity, is supported. That is why the present work hypothesizes the influence that the brand image has on engagement in the luxury sector:
H5: Brand image positively affects engagement in the luxury sector

\section{METHODOLOGY}

To carry out the research, a study was raised among buyers of luxury brands, conducting interviews with 310 people, 44 were carried out physically to consumers who bought in luxury brand stores and 266 online using the Google questionnaire tool, interviewing luxury brand consumers through different blogs and social networks. These surveys were carried out between the months of December 2018 and April 2019, targeting men (66,77\%) and women $(33,23 \%)$ who consume luxury brands or masstige. Of those interviewed, $0,97 \%$ are in the age range of 17 or less. Next range is 65 years or older with $2,26 \%$, followed by ages $55-64$ with $7,10 \%$. The respondents who are between 18 and 24 years old were $16,45 \%$ and, those who belong to the range of 25 to 34 years, $18,06 \%$. All interviews were conducted with residents in Spain.

A questionnaire with 29 closed questions with a Likert response scale of 1 to 5 was used for this purpose, in order to obtain data necessary to establish the existence of relationships between the variables indicated above. The first 4 questions referred to the characteristics of the respondent, while the rest of the questions were grouped according to the variables to be analyzed: awareness, loyalty, brand image and active commitment.

Table 1 shows the different items used in the questionnaire, as well as the authors that were taken as the basis for its redaction.

Table 1

Constructs, items and references used in the questionnaire

\begin{tabular}{|c|c|c|}
\hline Constructs & Items & References \\
\hline Brand & I know the brand of the product purchased. & Yoo et al. (2000) \\
\hline \multirow[t]{4}{*}{ Awareness } & I can easily recognize the logo or symbol of the brand of the product purchased. & Liu et al. (2017) \\
\hline & I can recognize the brand of the purchased product against other brands. & Buil et al. (2013) \\
\hline & When I think of luxury brands, the brand of the purchased product comes to mind. & Buil et al. (2013) \\
\hline & I have no difficulty in imagining products of the brand of the purchased product. & Yoo et al. (2000) \\
\hline \multirow[t]{5}{*}{ Brand Image } & The brand of the purchased product has personality. & Aaker (1996) \\
\hline & $\begin{array}{l}\text { The brand image of the purchased product is unique compared to the brand of the } \\
\text { competitors. }\end{array}$ & Liu et al. (2017) \\
\hline & I trust the brand of the purchased product. & Pappu et al. (2006) \\
\hline & I am proud to buy the brand of the purchased product. & Pappu and Quester (2006) \\
\hline & The brand of the purchased product symbolizes my status. & Sweeney and Soutar (2001) \\
\hline \multirow[t]{2}{*}{ Brand Loyalty } & I am loyal to the brand of the purchased product. & Liu et al. (2017) \\
\hline & I would not consider other brands if the brand of the purchased product is & Ding and Tseng (2015) \\
\hline
\end{tabular}
available.

The brand of the purchased product is my first choice when buying products of this type.

I would recommend the product brand to my friends.

I would switch to another brand if I experience a problem with the brand of the purchased product.

Engagement I feel I have a special relationship with the brand of the product purchased. I like to feel associated with the brand of the purchased product. I feel that the brand of the purchased product takes my opinions into account. If someone asks me, I will speak well of the brand of the product purchased. The brand of the purchased product and I are committed to achieving mutual satisfaction.

Ding and Tseng (2015)

Swoboda et al. (2013)

Musekiwa et al. (2013)

Sprott et al. (2009)

Cambra et al. (2012)

Blasco et al. (2011)

Blasco et al. (2011)

Cambra et al. (2012)

Source: Developed by the authors.

The items chosen for the awareness analysis come from different sources, being Yoo et al. (2000) the guide for several of the afore mentioned researchers. It is important to mention that the selected items are not always literal compilations of the authors' research, since, as with the last item of the brand image, it is necessary to adapt the 
measurement factors to the specific case of the luxury sector. Brand loyalty is one of the components most studied by researchers, which explains the large number of authors who propose the different items used. Most studies, however, use as a basis the items chosen by Aaker (1996) and Yoo et al. (2000). Although the items used to measure engagement are taken from the studies by Sprott et al. (2009), Blasco et al. (2011) and Cambra et al. (2012), they have been adapted to orient them to the luxury sector, emphasizing the brand of the high-end product that has been acquired.

Firstly, descriptive statistics, correlations, and internal consistency of all variables of interest were examined, using SPSS v.24. Secondly, a theoretical model was specified and tested by Confirmatory Factor Analysis (CFA). The proposed model specified how Brand Awareness affected Loyalty and Engagement though Image as a mediator, while both Loyalty and Engagement were correlated. Indirect effects of Brand Awareness on Loyalty and Engagement were also examined.

Confirmatory analysis was specified and estimated in Mplus 8 (Muthén \& Muthén, 1998-2017). Missing data were handle $\chi^{2} \mathrm{~d}$ with Full Information Maximum Likelihood. Weighted Least Square Mean and Variance corrected (WLSMV) method of estimation was employed to overcome the non-normality and ordinal nature of the items (Finney \& Di Stefano, 2006). Model overall fit was assessed with the chi-square, the CFI, and RMSEA. A good fit of the model was considered with $\mathrm{CFI}$ above .90 (better if it is above .95) and RMSEA below .08 (Marsh, Hau, \& Wen, 2004). It is known that RMSEA index does not perform optimally on models with small degrees of freedom, so Kenny, Kaniskan, and McCoach (2015) recommend using the SRMR index in those cases, which should be below .05 for a model to fit properly. Additionally, it was also considered the estimates of each parameter.

\section{FINDINGS}

\subsection{Confirmatory Factor Analyses}

A path analysis with Image as a mediator between Brand Awareness, and Loyalty and Engagement as specified and estimated. The model had a good fit to the data with $\chi^{2}(2)=8.118, \mathrm{p}<.05$, RMSEA $=.140[90 \% \mathrm{Cl}$ .050 - .247], SRMR $=.041$, and $\mathrm{CFI}=.963$. Brand Awareness had a positive effect on Image, and Image has a strong positive effect on Loyalty, and also on Engagement. Loyalty and Engagement were positively correlated. Additionally, Brand Awareness had an indirect, positive effect on Loyalty, as well as on Engagement. Altogether, the model explained $21 \%$ of the variance of Image, $22.2 \%$ of the variance on Engagement and $49.3 \%$ of the variance of Loyalty as it is shown in Figure 1.

\subsection{Descriptive statistics, correlations, and internal consistency}

Among the variables, Brand Awareness is the variable with highest mean, followed by Loyalty, Image, and finally, Engagement. The highest internal consistency of all four is the Cronbach Alpha of Engagement, followed by Loyalty, Image, and finally, Brand Awareness.

Regarding the bivariate correlations among the variables, all correlations are significative and positive except the correlation between engagement and brand awareness. The highest correlation is between Loyalty and Image, while the lowest is between Loyalty and Brand Awareness.

Table 2

Descriptive statistics, internal consistency, and correlations among the variables

\begin{tabular}{|c|c|c|c|c|c|c|}
\hline & Mean (SD) & $\alpha$ & 1 & 2 & 3 & 4 \\
\hline 1. Brand Awareness & $4.495(0.59)$ & .692 & .699 & & & \\
\hline 2. Brand Image & $3.992(0.71)$ & .695 & $.424^{* *}$ & .601 & & \\
\hline 3. Brand Loyalty & $3.998(0.73)$ & .730 & $.407^{\star *}$ & $.691^{* *}$ & .509 & \\
\hline 4. Engagement & $3.332(1.01)$ & .839 & .080 & $.578^{* *}$ & $.528^{* *}$ & .641 \\
\hline
\end{tabular}

Source: Developed by the authors.

Note: ${ }^{* *}<: .01$. AVE in the diagonal of the Matrix. Correlations reported in the lower half of the matrix.

Hypothesis have been tested running a structural equations model. The coefficients of the path analysis are shown in Table 3 and Figure 1 bellow. Each hypothesis has resulted to be significant for a $p$-value $<0.001$, and we can assume a significant positive correlation between every proposed relation.

Table 3

Results of the structural model

\begin{tabular}{|c|c|c|c|c|c|c|c|c|c|}
\hline \multirow[t]{2}{*}{ Effects } & \multicolumn{3}{|c|}{ Brand Loyalty } & \multicolumn{3}{|c|}{ Engagement } & \multicolumn{3}{|c|}{ Brand Image } \\
\hline & & Path Coeff & t-value & & Path Coeff & t-value & & Path Coeff & t-value \\
\hline Brand Image & $\mathrm{H} 4$ & 0.702 & $16.233^{* * *}$ & $\mathrm{H} 5$ & 0.472 & $8.040^{* * *}$ & & & \\
\hline Engagement & & 0.248 & $3.638^{* * *}$ & & & & & & \\
\hline Brand Awareness & $\mathrm{H} 2$ & 0.322 & $4.806^{\star \star *}$ & H3 & 0.216 & $5.048^{* * *}$ & $\mathrm{H} 1$ & 0.459 & $5.820^{* * *}$ \\
\hline Brand Loyalty & & & & & 0.248 & $3.638^{\star \star \star}$ & & & \\
\hline
\end{tabular}

Source: Developed by the authors.

Note: ${ }^{* * *} p<.001, N=310$ 


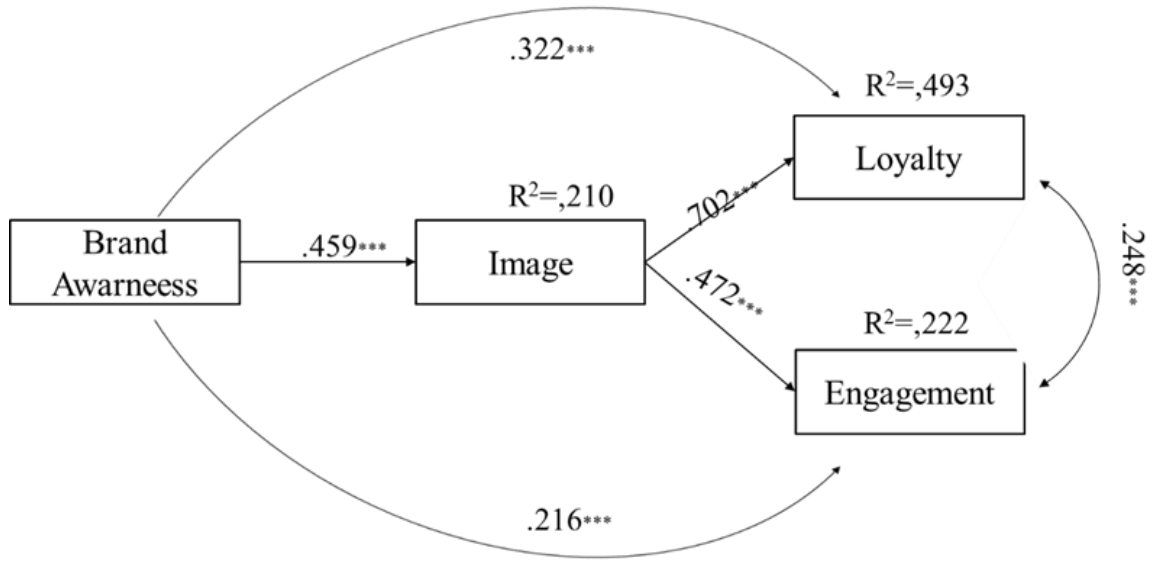

Figure 1. Model with standardized estimates $\left({ }^{* \star *} p<.001\right)$.

Source: Developed by the authors.

\section{DISCUSSION}

This study examined how Brand awareness, image, loyalty and engagement are related to each other in the formation of Brand Equity in the luxury sector. Although awareness, image and brand loyalty have been widely studied as contributors to the formation of Brand Equity, engagement is a relatively new concept within this field, since, as indicated by Gómez et al. (2019), the consumer brand engagement construct is still in its infancy.

According to the results obtained, brand awareness has a positive effect on image in the field of luxury brands, which is consistent with studies that in other areas provide authors such as Chang (2012), Barreda (2015) and Bilgin (2018) who points out that on social media marketing activities, brand awareness has a significant effect on brand image. Brand awareness also has as an indirect positive effect on loyalty when talking about luxury brands coinciding with the studies carried out by authors such as Martínez et al. (2014), Sasmita and Suki (2015) or Aberdeen et al. (2016) in other areas. The present study confirms the positive influence of brand awareness on engagement in the luxury brand sector, which is in the same line as the results obtained by Rhaman et al. (2020) for whom brand awareness is a fundamental driving force for the consumer decision-making.

On the other hand, brand image has a strong positive effect on loyalty in the luxury brands, confirming what the studies of authors like Kotsi et al. (2018) and Bilgin (2018) had contributed in sectors such as tourist destinations and others. It has been possible to verify the existence of a direct and moderate relationship between the image of luxury brands and loyalty, as in the study by Hanzaee and Farsani (2011), who argue that the brand image has a strong relationship with both present and future loyalty.

The results allow to conclude that awareness of luxury brands exerts a positive influence on consumer loyalty towards the brand, which is in line with studies such as that of Gallart-Camahort (2021) on retail, according to which retailer awareness positively affects loyalty. The effect of brand image is also strong on engagement which makes this not differ from other sectors, as the studies of Greve (2014).

The results also conclude that loyalty and engagement are positively correlated in the luxury sector. The results related to Engagement, defined as the intensity of an individual participation and connection with what the company offers (Hollebeek, 2011), follow the conclusions of the study by Banyte and Dovaliene (2014) in which it is shown that commitment has a direct relationship with consumer attitudinal loyalty, which directly influences brand equity.

\section{CONCLUSION}

As a consequence of this work, a series of conclusions can be drawn. First of all, it should be noted that, although engagement is a concept that has not been studied in the literature in terms of its contribution to the creation of Brand Equity, although, as indicated by Hollebeek et al. (2014) more and more is being taken into account when measuring the value of a brand, we see how in the luxury brand sector engagement is related to some of the variables that Keller (1993) and Aaker (1996) are part of the Brand Equity construct.

In this way, managers responsible for marketing luxury brands should keep in mind that awareness has a positive influence on customer loyalty and engagement towards the brand, which is especially important if we consider that loyal customers generally have a higher payment intention and lower price sensitivity compared to other customers (Jorgensen et al., 2016). Moreover, for Keller (2003), achieving brand loyalty is the main source of generating value for a brand from the customer's perspective.

In this way, luxury brands should pay special attention not only to achieve awareness, but also that this awareness is achieved among their target audience, since it is this audience that will be in a position to be more loyal to the brand.

On the other hand, and for similar reasons, luxury brands should take care of their image in front of their potential consumers since, as is clear from the present 
study, the image positively influences both loyalty and consumer engagement, aspects that, as it has been said, are vitally important to achieve good brand performance.

The study has some limitations derived from the fact that the population under study has been limited to residents of Spain. Since the scope of the luxury market has a clear international character, it would be interesting if future studies could expand the origin of the interviewees in terms of their nationality and residence. Another possible consideration would be to take into account the possible differences based on the sex or even the age of the target audience.

Finally, the study has taken into account luxury brands in general, without differentiating by the type of product, which could be taken into account in future studies.

\section{REFERENCES}

Aaker, D. (1991). Managing brand equity: Capitalizing on the value of a brand name. New York: The Free Press.

Aaker, D. (1996). Measuring brand equity across products and markets. California Management Review, 38(3), 102-120. https://doi.org/10.2307/41165845

Aberdeen, N. I., Syamsum, M., \& Najib, M. (2016). The effect of brand awareness and image on consumer perceived quality and purchase intention - A study case of carbonated drink brand at Bogor City. International Journal of Scientific and Research Publications, 6(8), 441-446.

Ajzen, I. (1991). The theory of planned behavior. Organizational Behavior and Human Decision Processes, 50(2), 179-211. https://doi.org/10.1016/0749-5978(91)90020-T

Andreassen, T., \& Lindestand, B. (1998). Customer loyalty and complex services: The impact of corporate image on quality, customer satisfaction and loyalty for customer with varying degrees of service expertise. International Journal of Service Industry Management, 9, 7-23. https://doi.org/10.1108/09564239810199923

Auh, S., Bell, S., McLeod, C., \& Shih, E. (2007). Co-production and customer loyalty in financial services. Journal of Retailing, 83, 359-370. https://doi.org/ 10.1016/j.jretai.2007.03.001

Baldinger, A. L., \& Rubinson, J. (1996). Brand loyalty: The link between attitude and behavior. Journal of Advertising Research, 36(2), 22-36.

Banyte, J., \& Dovaliene, A. (2014). Relations between customer engagement into value creation and customer loyalty. Social and Behavioral Sciences, 156, 484-489. https://doi.org/ 10.1016/..sbspro.2014.11.226

Berthon, P., Pitt, L., Parent, M., \& Berthon, J. (2009). Aesthetics and ephemerality: Observing and preserving the luxury brand. Business Horizons, 1, 45-66. https://doi.org/ 10.1525/cmr.2009.52.1.45

Bilgin, Y. (2018). The effect of social media marketing activities on brand awareness, brand image and brand loyalty. Business \& Management Studies: An International Journal, 6(1), 128148. https://doi.org/10.15295/bmij.v6i1.229

Blasco, L., Hernandez, B., \& Jimenez, J. (2011). Co-creation processes and engagement: An empirical approach. In E. Gummesson, C. Mele \& F. Polese (Eds.). Service dominant logic, network \& systems theory and service science. Giannini: Napoli.

Boo, S., Busser, J., \& Baloghu, S. (2008). A Model of customerbased brand equity and its application to multiple destinations. Tourism Management, 30, 219-231. https:/doi.org/10.1016/j.tourman.2008.06.003
Bowden, J. (2009). The process of customer engagement: A conceptual framework. Journal of Marketing Theory and Practice, 1, 63-74. https://doi.org/10.2753/MTP1069$\underline{6679170105}$

Brodie, R., Hollebeek, L., Jurić, B., \& Ilić, A. (2011). Customer engagement: Conceptual domain, fundamental proposition, and implications for research. Journal of Service Research, 3, 252-271. https://doi.org/10.1016/j.jbusres.2011.07.029

Buil, I., De Chernatony, L., \& Martinez, E. (2013). La importancia de medir el valor de marca desde la perspectiva de consumidor: Evidencia empírica en España y Reino Unido. Revista de Ciencias Sociales, 2, 226-237.

Cambra, J., Melero, I., \& Sese, J. (2012). Aproximación al concepto de engagement: Un estudio exploratorio en el sector de la telefonía móvil, Universia Business Review, 33, 84-103.

Castaldo, S., Grosso, M., Mallarini, E., \& Rindone, M. (2015). The missing path to gain customers loyalty in pharmacy retail: The role of the store in developing satisfaction and trust. Research in Social and Administrative Pharmacy, 12(5), 699-712. https://doi.org/10.1016/j.sapharm.2015.10.001

Chang, Y. H. (2012). A study on the marketing performance using social media - Comparison between portal advertisement, blog, and SNS channel characteristics and performance. Journal of Digital Policy \& Management, 8(10), 119-133. https://doi.org/10.14400/JDPM.2012.10.8.119

Dhaoui, C. (2014). An empirical study of luxury brand marketing effectiveness and its impact on consumer engagement on Facebook. Journal of Global Fashion Marketing, 5(3), 209233. https://doi.org/10.1080/20932685.2014.907605

Ding, C., \& Tseng, T. (2015). On the relationships among brand experience, hedonic emotions, and brand equity. European Journal of Marketing, 49, 994-1007. https://doi.org/ 10.1108/EJM-04-2013-0200

Dubois, B., Laurent, G., \& Czellar, S. (2001). Consumer rapport to luxury: Analyzing complex and ambivalent attitudes. Consumer Research, Working Paper, n. 736. France: HEC.

Farhat, K., Mokhtar, S. S. M., \& Salleh, S. M. (2020). Linking brand engagement to customer-based brand equity and role of brand experience, brand personality, and brand affect: A case of automobile market of Pakistan, Management Science Letters, 10, 2237-2248. https://doi.org/10.5267/j.msl.2020.3.012

Farquhar, P. (1989). Managing brand equity. Marketing Research, 1, 24-33.

Finney, S. J., \& Di Stefano, C. (2006). Non-normal and categorical data in SEM. In G. R. Hancock \& R. O. Mueller (Eds.). Structural equation modelling: $A$ second course. Greenwich, CO: Information Age Publishing.

Gallart-Camahort V., Callarisa-Fiol, L., \& Sanchez-García, J. (2021). Influence of the internet on retailer's perceived quality in the generation of retailer's brand equity. Vision: The Journal of Business Perspective. https://doi.org/10.1177/0972262921992212

Gambetti, R. C., \& Graffigna, G. (2010). The concept of engagement: A systematic analysis of the ongoing marketing debate. International Journal of Market Research, 52(6), 801-826. https://doi.org/ $\underline{10.2501 / \mathrm{S} 147078531020166}$

Gómez, M., Lopez, C., \& Molina, A. (2019). An integrated model of social media brand engagement. Computers in Human Behavior, 96, 196-206. https://doi.org/10.1016/j.chb.2019.01.026

Grassi, A. (2020). Art to enhance consumer engagement in the luxury fashion domain. Journal of Fashion Marketing and Management: An International Journal, 24(3), 327-341. https://doi.org/10.1108/JFMM-09-2019-0194 
Gremler, D. D., \& S. W. Brown (1996). Service loyalty: Its nature, importance, and implications. In B. Edvardsson, S. W. Brown \& R. Johnston (Eds.). Advancing service quality: $A$ global perspective. New York: International Service Quality Association.

Greve, G. (2014). The moderating effect of customer engagement on the brand image - Brand loyalty relationship. Procedia Social and Behavioral Sciences. 148, 203-210. https://doi.org/10.1016/j.sbspro.2014.07.035

Hagtvedt, H., \& Patrick, V. (2009). The broad embrace of luxury: Hedonic potential as a driver of brand extendibility. Journal of Consumer Psychology, 4, 608-618. https://doi.org/ 10.1016/j.jcps.2009.05.007

Hanzaee, K., \& Farsani, F. (2011). The effects of brand image and perceived public relation on customer loyalty. World Applied Sciences Journal, 2, 277-286.

Heine, K. (2012). The concept of luxury brands. Écully: Goldman \& Vredenburgh. http://upmarkit.com/sites/default/files/content/20130403 H eine The Concept of Luxury Brands.pdf

Higgins, T., \& Scholer, A. (2009). Engaging the consumer: The science and art of the value creation process. Journal of Consumer Psychology, 2, 100-114. https://doi.org/ 10.1016/j.jcps.2009.02.002

Hollebeek, L. D. (2011). Exploring customer brand engagement: Definition and themes. Journal of Strategic Marketing, 19(7), https://doi.org/10.1080/0267257X.2010.500132

Huang, R., \& Sarigöllü, E. (2012). How brand awareness relates to market outcome, brand equity, and the marketing mix. Journal of Business Research, 65(1), 92-99. https://doi.org/10.1007/978-1-4939-0277-4 8

Ismail, A. R. (2015). Leveraging the potential of word of mouth: The role of love, excitement and image of fashion brands. Journal of Global Fashion Marketing, 6(2), 87-104. https://doi.org/10.1080/20932685.2014.999013

Jara, M., \& Cliquet, G. (2007). Retail brand equity: A conceptual and differentiated approach. European Association of Education and Research in Commercial Distribution, Germany, https://doi.org/10.1016/j.jretconser.2011.11.003

Johnson, M., Andreessen, T., Lervik, L., \& Cha, J. (2001). The evolution and future of national customer satisfaction index models. Journal of Economic Psychology, 22, 217-245. https://doi.org/10.1016/S0167-4870(01)00030-7.

Jorgensen, F., Mathisen, T. A., \& Pedersen, H. (2016). Brand loyalty among Norwegian car owners. Journal of Retailing and Consumer Services, 31, 256-264. https://doi.org/ 10.1016/j.jretconser.2016.04.001

Kapferer, J. (1997). Managing Luxury Brands. Journal of Brand Management, 4, 251-260.

Keller, K. (1993). Conceptualizing, measuring and managing customer-based brand equity. Journal of Marketing, 57, 122. https://doi.org/10.2307/1252054

Keller, K. L. (2003). Strategic brand management: Building, measuring, and managing brand equity. Upper Saddle River, NJ: Prentice-Hall.

Keller, K. (2009). Managing the growth tradeoff: Challenges and opportunities in luxury branding. Journal of Brand Management, 5, 290-301. https://doi.org/10.1007/978-3319-51127-6 9

Kenny, D. A., Kaniskan, B., \& McCoach, D. B. (2015). The performance of RMSEA in models with small degrees of freedom. Sociological Methods \& Research, 44, 486-507. https://doi.org/ 10.1177/0049124114543236

Kim, A., \& Ko, E. (2012). Do social media marketing activities enhace customer equity? An empirical study of luxury fashion brand. Journal of Business Research, 65, 1480

1486. https://doi.org/10.1016/j.jbusres.2011.10.014

Kim, H., \& Kim, W. (2005). The relationship between brand equity and firms' performances in luxury hotels and chain restaurants. Tourism Management, 26, 549-560. https://doi.org/10.1016/j.tourman.2004.03.010

Ko, E., Costello, J., \& Taylor, C. (2017). What is luxury brand? A new definition and review of the literature. Journal of Business Research, 99, 405-413. https://doi.org/10.1016/j.jbusres.2017.08.023

Kotler, P. (2002). Marketing Management (Millennium Edition). Boston: Pearson Custom Publishing.

Kotler, P., \& Keller, K. (2016). Dirección de Marketing. México: Pearson.

Kotsi, F., Pike, S., \& Gottlieb, U. (2018). Consumer-based brand equity (CBBE) in the context of an international stopover destination: Perceptions of Dubai in France and Australia. Tourism Management, 69, 297306https://doi.org/10.1016/j.tourman.2018.06.019

Kuvykaite, R., \& Piligrimiene, Z. (2014). Consumer engagement into brand equity creation, Journal of Business Research, 156, 479-483. https://doi.org/10.1016/j.sbspro.2014.11.225

Lassar, W., Mittal, B., \& Sharma, A. (1995). Measuring customerbased brand equity. Journal of Consumer Marketing, 12 , 11-19. https://doi.org/10.1108/07363769510095270

Liu, G., Liston-Heyes, C., \& Ko, W. W. (2010). Employee participation in cause-related marketing strategies: A study of management perceptions from British consumer service industries. Journal of Business Ethics, 92, 195-210. https://doi.org/10.1007/s10551-009-0148-3

Liu, M., Wong, A., Tseng, T., \&Chang, A. (2017). Applying consumer-based brand equity in luxury hotel branding. Journal of Business Research, 81, 192-202. https://doi.org/10.1016/j.jbusres.2017.06.014

MacDonald, E., \& Sharp, B. (2000). brand awareness effects on consumer decision making for a common, repeat purchase product: A replication. Journal of Business Research, 1, 515. https://doi.org/10.1016/S0148-2963(98)00070-8

Marsh, H. W., Hau, K. T., \& Wen, Z. (2004). In search of golden rules: Comment on hypothesis-testing approaches to setting cutoff values for fit indexes and dangers in overgeneralizing $\mathrm{Hu}$ and Bentler's (1999) findings. Structural Equation Modeling, 11, 320-341. https://doi.org/10.1207/s15328007sem11032

Martínez, P., Pérez, A., \& Bosque, I. R. (2014). CSR influence on hotel brand image and loyalty. Academia Revista Latinoamericana de Administración, 27(2), 267-283. https://doi.org/10.1108/ARLA-12-2013-0190

Matos, C., \& Rossi, C. (2008). Word-of-mouth communications in marketing: A meta-analytic review of the antecedents and moderators. Journal of the Academy of Marketing Science, 36, 578-596.

Musekiwa, A., Chiguvi, D., \& Hogo, H. (2013). customer based retail brand equity (RBE) dimensions effect on retail brand equity for OK Supermarket in Bindura. International Center of Business and Management, 8, 45-54 https://doi.org/10.5539/ijbm.v8n19p45

Neff, J. (2007). OMD proves the power of engagement, Advertising Age, 78.

Nueno, J., \& Quelch, J. (1998). The mass marketing of luxury. Business Horizons, 41(6), 61-68. https://doi.org/10.1016/S0007-6813(98)90023-4

Odin, Y., Odin, N., \& Valette-Florence, P. (2001). Conceptual and operational aspects of brand loyalty: An empirical investigation. Journal of Business Research, 53(2), 7-84. https://doi.org/10.1016/S0148-2963(99)00076-4

Pansari, A. \& Kumar, V. (2017). Customer engagement: the constructs, antecedents and consequences. Journal of the 
Gallart-Camahort, Ramos \& Fernandez-Duran - Luxury brands: Awareness and image and its influence on loyalty and engagement Academy of Marketing Science, 45(3), 294-311. $\quad$ and Tourism Management, 40, 114-124. https://doi.org/10.1007/s11747-016-0485-6

Pappu, R., \& Quester, P. (2006). Does consumer satisfaction lead to improved brand equity? An empirical examination of two categories of retail brands. Journal of Product \& Brand Manangement,

15 ,

4-14. https://doi.org/10.1108/10610420610650837

Pappu, R., Quester, P., \& Cooksey, R. (2006). Consumer-bassed brand equity and country-of-origin relationships. European Journal of Marketing, 40, 696-717. https://doi.org/10.1108/03090560610657903

Patterson, P., Ting, Y., \& De Ruyter, K. (2006). Understanding customer engagement in services. Proceedings of ANZMAC Conference, Australia.

Prasad, K., \& Dev, C. (2000). Managing hotel brand equity: A customer-centric framework for assessing performance. Cornell Hotel and Restaurant Administration Quarterly, 3, 22-31. https://doi.org/10.1016/S0010-8804(00)80014-2

Rajah, E., Marshall, R., \& Nam, I. (2008). Relationship glue: Customers and marketers co-creating a purchase experience. Advances in Consumer Research, 35, 367373.

Rahman, M. S., Hossain, M. A., Hoque, M. T., Rushan, M. R. I., \& Rahman, M. I. (2020). Millennials' purchasing behavior toward fashion clothing brands: Influence of brand awareness and brand schematicity. Journal of Fashion Marketing and Management: An International Journal, 25(1), 153-183. https://doi.org/10.1108/jfmm-07-2019-0137

Rappaport, S. (2007). Lessons from Online Practice: New Advertising Models. Journal of Advertising Research, 7, 135-141.

Rauyruen, P., \& Miller, K.E. (2007). Relationship quality as a predictor of B2B customer loyalty. Journal of Business Research 60(1),

21-31. https://doi.org/10.2501/S0021849907070158

Romaniuk, J., Wight, S., \& Faulkner, M. (2017). Brand awareness: Revisiting an old metric for a new world. Journal of Product

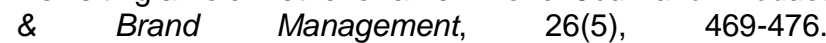
https://doi.org/10.1108/JPBM-06-2016-1242

Sashi, C. (2012). Customer engagement, buyer-seller relationships, and social media. Management Decisions, 50, 253-272. https://doi.org/10.1108/00251741211203551

Sasmita, J., \& Suki, N. M. (2015). Young consumers' insights on brand equity effects of brand association, brand loyalty, brand awareness, and brand image. International Journal of Retail \& Distribution Management, 43(3), 276-292. https://doi.org/10.1108/IJRDM-02-2014-0024

Schivinski, B., \& Dabrowski, D. (2015). The impact of brand communication on brand equity through Facebook. Journal of Research in Interactive Marketing, 9, 31-53. https://doi.org/10.1108/JRIM-02-2014-0007

Seetharaman, A., Nadzir, Z. A. B. M., \& Gunalan, S. (2001). A conceptual study on brand valuation. The Journal of Product and Brand Management, (10)4, 243-256. https://doi.org/10.1108/EUM0000000005674

Shamma, H., \& Hassan, S. (2011). Integrating product and corporate brand equity into total brand equity measurement. International Journal of Marketing Studies, 3, 11-20.

Sprott, D., Czellar, S., \& Spangenberg, E. (2009). The importance of a general measure of brand engagement on market behavior: Development and validation of a scale. Journal of Marketing Research, 46, 92-104. https://doi.org/10.1509/jmkr.46.1.92

Sürücü, Ö., Öztürk, Y., Okumus, F., \& Bilghan, A. (2019). Brand awareness, image, physical quality and employee behavior as building blocks of customer-based brand equity: Consequences in the hotel contexto. Journal of Hospitality
https://doi.org/10.1016/J.JHTM.2019.07.002

Sweeney, J., \& Soutar, G. (2001). Consumer perceived value: The development of a multiple item scale. Journal of Retailing, 77, 203-220. https://doi.org/10.1016/S0022 4359(01)00041-0

Switala, M., Gamrot, W., Reformat, B., \& Bilinska-Reformat, K. (2018). The influence of brand awareness and brand image on brand equity - an empirical study of logistics service providers. Journal of Economics and Management, 33(3), 97-119. https://doi.org/10.22367/jem.2018.33.06

Swoboda, B., Berg, B., Schramm-Klein, H., \& Foscht, T. (2013). The importance of retail brand equit and store accessibility for store loyalty in local competition. Journal of Retailing and Consumer Services, 20, 251-262. https://doi.org/10.1016/j.jretconser.2013.01.011

Tybout, A., \& Artz, N. (1994). Consumer Psychology. Annual Review of Psychology, 45, 131-169. https://doi.org/10.1146/annurev.ps.45.020194.001023

Van Doorn, J., Lemon, K., Mittal, V., Nass, S., Pick, D., Pirner, P., \& Verhoef, P. (2010). Customer engagement behavior: Theoretical foundations and research directions. Journal of Service Research, 3, 253-266. https://doi.org/10.1177/1094670510375599

Vigneron, F., \& Johnson, L. (2004). Measuring brand luxury perceptions. The Journal of Brand Management, 11, 484508.

Voyles, B. (2007). Beyond loyalty: Meeting the challenge of customer engagement. London: Economist Intelligence Unit.

Wood, L. (2000). Brands and brand equity: Definition and management. Management Decision, 38(9), 662-669. https://doi.org/10.1108/00251740010379100

Wu, W. Y., Do, T. Y., Nguyen, P. T., Anridho, N., \& Vu, M. Q. (2020). An integrated framework of customer-based brand equity and theory of planned behavior: A meta-analysis approach. Journal of Asian Finance Economics and Business, 7(8), 371-381. https://doi.org/10.13106/jafeb.2020.vol7.no8.371

Xi, N., \& Hamari, J. (2020). Does gamification affect brand engagement and equity? A study in online brand communities. Journal of Business Research, 109, 449-460. https://doi.org/10.1016/j.jbusres.2019.11.058

Yoo, B., Donthu, N., \& Lee, S. (2000). An examination of selected marketing mix elements and brand equity. Journal of Marketing Research, 21, 799-822. https://doi.org/ 10.1177/0092070300282002 


\section{CONTEXTUS}

REVISTA CONTEMPORÂNEA DE ECONOMIA E GESTÃO

\section{CONTEXTUS}

CONTEMPORARY JOURNAL OF ECONOMICS AND

MANAGEMENT.

ISSN 1678-2089

\section{ISSNe 2178-9258}

1. Economics, Administration and Accounting - Journal

2. Federal University of Ceará. Faculty of Economics,

Administration, Actuaries and Accounting

\section{FACULTY OF ECONOMICS, ADMINISTRATION, ACTUARIES}

\section{AND ACCOUNTING}

University Av. - 2486, Benfica

60020-180, Fortaleza-CE

BOARD: Paulo Rogério Faustino Matos Danielle Augusto Peres

Website: www.periodicos.ufc.br/contextus

E-mail: revistacontextus@ufc.br

\section{CONTEXTUS REVISA CONIEPOPENAEA DE ECONOMIA E GESTÃO}

UNIVERSIDADE FEDERAL

DO CEARÁ

FACULDADE

DE ECONOMIA,

ADMINISTRAÇÃO, ATUÁRIA

E CONTABILIDADE

\section{Qualis}

DORA

ABBEC

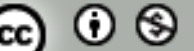

Contextus is classified in the Qualis - Capes system as a B1 journal, in the area of Public and Business Administration, Accounting and Tourism (2013-2016).

Contextus agrees and signs the San Francisco Declaration on Research Assessment (DORA).

Contextus is associated with the Brazilian Association of Scientific Editors.

This work is licensed under a Creative Commons Attribution - NonCommercial 4.0 International license.
EDITOR-IN-CHIEF

Diego de Queiroz Machado (UFC)

\section{ASSISTANT EDITORS}

Alane Siqueira Rocha (UFC)

Márcia Zabdiele Moreira (UFC)

\section{ASSOCIATE EDITORS}

Adriana Rodrigues Silva (IPSantarém, Portugal)

Alessandra de Sá Mello da Costa (PUC-Rio)

Allysson Allex Araújo (UFC)

Andrew Beheregarai Finger (UFAL)

Armindo dos Santos de Sousa Teodósio (PUC-MG)

Brunno Fernandes da Silva Gaião (UEPB)

Carlos Enrique Carrasco Gutierrez (UCB)

Dalton Chaves Vilela Júnior (UFAM)

Elionor Farah Jreige Weffort (FECAP)

Gabriel Moreira Campos (UFES)

Guilherme Jonas Costa da Silva (UFU)

Henrique César Muzzio de Paiva Barroso (UFPE)

Jorge de Souza Bispo (UFBA)

Keysa Manuela Cunha de Mascena (UNIFOR)

Manuel Anibal Silva Portugal Vasconcelos Ferreira (UNINOVE)

Marcos Cohen (PUC-Rio)

Marcos Ferreira Santos (La Sabana, Colombia)

Mariluce Paes-de-Souza (UNIR)

Minelle Enéas da Silva (La Rochelle, France)

Pedro Jácome de Moura Jr. (UFPB)

Rafael Fernandes de Mesquita (IFPI)

Rosimeire Pimentel (UFES)

Sonia Maria da Silva Gomes (UFBA)

Susana Jorge (UC, Portugal)

Thiago Henrique Moreira Goes (UFPR)

\section{EDITORIAL BOARD}

Ana Sílvia Rocha Ipiranga (UECE)

Conceição de Maria Pinheiro Barros (UFC)

Danielle Augusto Peres (UFC)

Diego de Queiroz Machado (UFC)

Editinete André da Rocha Garcia (UFC)

Emerson Luís Lemos Marinho (UFC)

Eveline Barbosa Silva Carvalho (UFC)

Fátima Regina Ney Matos (ISMT, Portugal)

Mario Henrique Ogasavara (ESPM)

Paulo Rogério Faustino Matos (UFC)

Rodrigo Bandeira-de-Mello (FGV-EAESP)

Vasco Almeida (ISMT, Portugal)

\section{SCIENTIFIC EDITORIAL BOARD}

Alexandre Reis Graeml (UTFPR)

Augusto Cezar de Aquino Cabral (UFC)

Denise Del Pra Netto Machado (FURB)

Ednilson Bernardes (Georgia Southern University, USA)

Ely Laureano Paiva (FGV-EAESP)

Eugenio Ávila Pedrozo (UFRGS)

Francisco José da Costa (UFPB)

Isak Kruglianskas (FEA-USP)

José Antônio Puppim de Oliveira (UCL)

José Carlos Barbieri (FGV-EAESP)

José Carlos Lázaro da Silva Filho (UFC)

José Célio de Andrade (UFBA)

Luciana Marques Vieira (UNISINOS)

Luciano Barin-Cruz (HEC Montréal, Canada)

Luis Carlos Di Serio (FGV-EAESP)

Marcelle Colares Oliveira (UFC)

Maria Ceci Araujo Misoczky (UFRGS)

Mônica Cavalcanti Sá Abreu (UFC)

Mozar José de Brito (UFL)

Renata Giovinazzo Spers (FEA-USP)

Sandra Maria dos Santos (UFC)

Walter Bataglia (MACKENZIE) 